\title{
Suppressive effects of dehydroepiandrosterone and the nuclear factor-кB inhibitor parthenolide on corticotroph tumor cell growth and function in vitro and in vivo
}

\author{
T Taguchi, T Takao, Y Iwasaki, M Nishiyama, K Asaba \\ and $\mathrm{K}$ Hashimoto \\ Department of Endocrinology, Metabolism and Nephrology, Kochi Medical School, Kochi University, Oko-cho, Kohasu, Nankoku 783-8505, Japan \\ (Requests for offprints should be addressed to T Taguchi; Email: tagu@muse.ocn.ne.jp)
}

\begin{abstract}
Dehydroepiandrosterone (DHEA) is believed to have an anti-tumor effect, as well as anti-inflammatory, antioxidant, and anti-aging effects. To clarify the possible inhibitory action of DHEA on pituitary tumor cells, we tested the effects of DHEA, alone or in combination with the nuclear factor- $\kappa \mathrm{B}(\mathrm{NF}-\kappa \mathrm{B})$ inhibitor parthenolide (PRT), on AtT20 corticotroph cell growth and function both in vitro and in vivo. We found that, in vitro, DHEA and PRT had potent inhibitory effects on pro-opiomelanocortin and NF-KB-dependent gene expression. They also suppressed the transcription activity of survivin, a representative anti-apoptotic factor, and induced apoptosis in this cell line. Furthermore, using BALB/C nude mice with
\end{abstract}

xenografts of AtT20 cells in vivo, we found that the combined administration of DHEA and PRT significantly attenuated tumor growth and survivin expression. The treatment also decreased the elevated plasma corticosterone levels and ameliorated the malnutrition induced by tumor growth. Altogether, these results suggested that combined treatments of DHEA and PRT potently inhibit the growth and function of corticotroph tumor cells both in vitro and in vivo. This effect may, at least partly, be caused by the suppressive effects of these compounds, such as survivin and other inhibitor of apoptosis proteins, on NF- $\mathrm{\kappa B}-$ mediated gene transcription.

Journal of Endocrinology (2006) 188, 321-331

\section{Introduction}

Adrenocorticotropin (ACTH)-dependent Cushing's syndrome, induced either by a corticotroph tumor in the pituitary or by an ectopic ACTH-producing tumor, is a life-threatening disease, causing metabolic derangements such as diabetes mellitus, hypertension, atherosclerosis, and immune dysfunction (Arnaldi et al. 2003). Although surgical treatments are essential for the disorder, medical treatment is sometimes necessary in cases with incomplete removal of the tumor, recurrence, or in cases unsuitable for surgical procedure. Paez-Perada et al. (2001) showed that retinoic acid, an inducer of cell differentiation, has potent inhibitory effects on Cushing's adenoma using AtT20 mouse corticotroph tumor cells as a model system. More recently, Heaney et al. (2002) reported the effectiveness of thiazolidinedione (TZD), a peroxisome proliferator-activated receptor (PPAR) $\gamma$ agonist, on this disorder, again using the AtT20 cell xenograft. Although the precise mechanism of the effect of TZD on the pituitary tumor cell has not yet been clarified, recent studies suggest that TZD acts as an inducer of apoptosis in some other tissues ( $\mathrm{Lu}$ et al. 2005, Shiau et al. 2005).
Dehydroepiandrosterone (DHEA) is an adrenal steroid which acts as a precursor of sex steroids such as androgen and estrogen (Miller 2002). Besides its effects as a prohormone, DHEA itself is suggested to have a variety of beneficial effects such as anti-tumor, anti-diabetic, antiatherosclerotic, and anti-aging effects (Aoki et al. 2003). Some of these effects are thought to be mediated by its antioxidant properties via inhibition of nuclear factor- $\kappa \mathrm{B}$ (NF-KB) (Aragno et al. 2002, Iwasaki et al. 2004), which is a transcription factor known to exert anti-apoptotic effects in neoplasia. DHEA is indeed reported to elicit cellular apoptosis in both tumor and non-tumor cells in vitro (Yang et al. 2000, Liang et al. 2004). Thus, it is possible that, like TZD, DHEA may exert negative effects on corticotroph tumor cell growth and function by inhibiting the NF- $\kappa \mathrm{B}$ signaling pathway.

The fate of normal cells is determined by the regulation of the apoptotic mechanism, a system of programmed cell death controlling cellular survival. In contrast, this mechanism is known to be inhibited in tumor cells, by the expression of anti-apoptotic factors such as inhibitors of apoptosis proteins (IAPs) (Ambrosini et al. 1997, Salvesen \& Duckett 2002, Schimmer 2004). Thus, induction of 
apoptosis by targeting these proteins is expected to be applicable for clinical cancer therapy (LaCasse et al. 1998). Although various IAPs are known to be expressed in tumor cells, some studies suggest that many of these factors, including survivin (Ambrosini et al. 1997, Swana et al. 1999), a representative IAP, are induced by the activation of the NF- $\mathrm{KB}$ pathway (LaCasse et al. 1998, Kawakami et al. 2005). Specific inhibition of this transcription factor is shown to induce apoptosis (Umezawa \& Chaicharoenpong 2002, Horiguchi et al. 2003). In this regard, a sesquiterpene lactone, parthenolide (PRT), may be an appropriate candidate, because it exerts a potent inhibitory effect on the NF- $\kappa B$ pathway with low toxicity. The effectiveness of this compound has already been shown for a variety of human tumor cells (Nakshatri et al. 2004). Furthermore, it is more effective when used in combination with conventional chemotherapy and radiotherapy (Patel et al. 2000, Riggins et al. 2005).

In this study, we have examined the effects of DHEA and PRT on ACTH-secreting pituitary tumors applying an in vitro and in vivo experimental model system previously used for the examination of medical therapy for Cushing's disease (Heaney et al. 2002). Because DHEA and PRT are not toxic in vivo, and both are known to have apoptosis-inducing as well as anti-NF- $\mathrm{KB}$ properties, we expected the combination of these reagents to have a more significant effect. Indeed, we found in this study that DHEA and PRT, either alone or in combination, inhibited corticotroph cell function in vitro, and that administration of both DHEA and PRT significantly attenuated the tumor growth in vivo. We also found that the treatment significantly reduced the expression of IAPs such as survivin and NF- $\mathrm{KB}$-dependent transcription.

\section{Materials and Methods}

\section{Materials}

NF- $\kappa \mathrm{B}$-luciferase reporter plasmid was purchased from Stratagene (La Jolla, CA, USA). DHEA was obtained from Wako Pure Chemicals (Osaka, Japan) and $17 \beta-$ estradiol $\left(\mathrm{E}_{2}\right)$, testosterone, and PRT were from Sigma Chemical Co.

\section{Cultivation and transfection}

AtT20/D16 v mouse corticotroph tumor cells, or a stable transformant of the cell (AtT20PL) in which the rat pro-opiomelanocortin (POMC) gene $5^{\prime}$-promoter $(-708$ to $+64 ;+1$ indicates the transcription start site)luciferase fusion gene was stably incorporated, was used in this study. Cells were maintained in a $T_{75}$ culture flask with Dulbecco's modified Eagles' medium supplemented with 10\% fetal bovine serum (Invitrogen) and antibiotics (50 $\mathrm{U} / \mathrm{ml}$ penicillin and $50 \mu \mathrm{g} / \mathrm{ml}$ streptomycin) under a
$5 \% \mathrm{CO}_{2}-95 \%$ air atmosphere at $37{ }^{\circ} \mathrm{C}$. For each experiment, cells were plated in 24-well culture dishes with approximately $70 \%$ confluence. For transient transfection experiments, AtT20 cells were transfected with a variety of reporter plasmids using the lipofection method.

\section{Cell culture experiments}

On the day of the experiment, stock solutions of test substances (DHEA, E 2 , PRT, and testosterone) were added directly to the serum-free culture medium of each dish, and the cells were incubated for $24 \mathrm{~h}$. At the end of each experiment, the culture media were removed, and the cells were harvested using lysis buffer. Luciferase assay for determining the promoter activity of POMC, survivin, and NF- $\mathrm{KB}$-luciferase was performed using a luciferase assay system (Promega) according to the manufacturer's instructions. ACTH secreted into the culture medium was measured by immunoradiometric assay (ACTH immunoradiometric assay kit; Mitsubishi Chemical, Tokyo, Japan).

\section{RT-PCR}

RNA was isolated using TRIZOL reagent (Invitrogen), and $2 \mu \mathrm{g}$ of the total RNA was used for the RT reaction by Superscript III reverse transcriptase (Invitrogen). The cDNAs obtained were then amplified by PCR with Taq DNA polymerase (Takara Shuzo, Kyoto, Japan). The sequences of primer sets for amplifying mouse IAPs were as follows: survivin forward, 5'-GCGGAGGCTG GCTTCA-3', reverse, 5'-CTTGGCTCTCTGTCTGT CCA-3'; mouse neuronal apoptosis inhibitory protein (mNAIP) forward, 5'-ACATCACCACGTGTACTC TCA-3', reverse, 5'-GGCTTCTGGAAGTGCACA GTG-3'; Bruce forward, 5'-GATCTTGTTGCTAGAC ACTGC-3', reverse, 5'-GGTCTCCCTTCTGTTAGC TTC-3'; X-linked inhibitor of apoptosis (XIAP) forward, 5'-GCAATGTTTCAGTTGTCATGCG-3', reverse, 5'-CCAGCACTAGCTAACTCTCTG-3'; inhibitor of apoptosis protein 1 (IAP1) forward, 5'-GACAAGGTCA AGTGCTTCTGC-3', reverse, 5'-CTTACGTTCCCA GTTGCTCAG-3'; inhibitor of apoptosis protein 2 (IAP2) forward, 5'-GTGTGAACTCTACCGAATGTC-3', reverse, 5'-CTGCGGTGCTCTGACATAGC-3'.

\section{Quantitative real-time $R T$-PCR}

RNA was isolated from liver and tumor tissues using Sepasol-RNA1 Super (Nacalai Tesque Inc., Kyoto, Japan) according to the manufacturer's instructions. cDNA was synthesized from $2 \mu \mathrm{g}$ RNA with Superscript III reverse transcriptase in the presence of $1 \mu \mathrm{g}$ random hexamer primers and $0.5 \mathrm{mM}$ dNTPs (Promega). In survivin cDNA-specific quantitative RT-PCR assay, the reaction 
mixture contained $10 \mu \mathrm{M}$ survivin-forward and $10 \mu \mathrm{M}$ survivin-reverse primers, $10 \mu \mathrm{M}$ TaqMan probe, $12 \cdot 5 \mu \mathrm{l}$ TaqMan Universal PCR Master Mix (Applied Biosystems, Foster City, CA, USA), $\mathrm{H}_{2} \mathrm{O}$, and $2 \mu \mathrm{l}$ cDNA, in a total volume of $25 \mu \mathrm{l}$. After enzyme activation $\left(2 \mathrm{~min}\right.$ at $50{ }^{\circ} \mathrm{C}$ and $10 \mathrm{~min}$ at $95^{\circ} \mathrm{C}$ ), 40 two-step cycles were performed $\left(15 \mathrm{~s}\right.$ at $95^{\circ} \mathrm{C}$ and $60 \mathrm{~s}$ at $\left.60^{\circ} \mathrm{C}\right)$ by ABI PRISM 7000 Sequence Detection System (Applied Biosystems). Mouse survivin primers and TaqMan probe were purchased from Applied Biosystems and designed as follows (Aziz et al. 2004): forward mouse survivin primer, 5'-GCGGAGGC TGGCTTCA-3', reverse mouse survivin primer, 5'CTTGGCTCTCTGTCTGTCCA-3'; TaqMan mouse survivin probe, 5'-CCACTGCCCTACCGAGAACGA GCC-3'. These yielded a $216 \mathrm{bp}$ product. Mouse glyceraldehyde-3-phosphate dehydrogenase (GAPDH) primers as an internal control were also purchased from Applied Biosystems. A standard curve was generated on the basis of a linear relationship between the first cycle number at which the fluorescence signal significantly increased (Ct value) and the logarithm of the starting quantity. The quantity of target mRNA in an unknown sample was determined from the $\mathrm{Ct}$ value using the standard curve. A control without template was included in each experiment. Non-template controls, standard dilutions, and samples were assayed in duplicate. After the relative gene expression levels for survivin value were established for each sample, these values of survivin were used for statistical analyses.

\section{Electrophoretic mobility shift assay (EMSA)}

EMSA was carried out using a Light Shift Chemiluminescent EMSA kit (Pierce Biotechnology, Rockford, IL, USA), following the manufacturer's instructions. Briefly, the extracted NF- $\mathrm{\kappa B}$ consensus oligonucleotides (5'-AGTTGAGGGGACTTTCCCAGG-3') were labeled with ${ }^{32} \mathrm{P}$-ATP using $\mathrm{T}_{4}$ polynucleotide kinase and purified on QIAquick nucleotide removal kit (Qiagen). Cells were treated with DHEA $(100 \mu \mathrm{M})$ or PRT $(10 \mu \mathrm{M})$ for $4 \mathrm{~h}$. For the EMSA, $50 \mu \mathrm{g}$ nuclear proteins were used. Briefly, the samples were incubated with 100000 c.p.m. ${ }^{32}$ P-labeled NF- $\mathrm{BB}$ oligonucleotide probe for $30 \mathrm{~min}$ at room temperature in binding buffer containing $35 \mathrm{~mm}$ HEPES-KOH, pH 7.8, 0.5 mm EDTA, $0.5 \mathrm{~mm}$ dithiothreitol, $10 \%$ glycerol, $0.25 \mathrm{~mm}$ Spermidine, and $0 \cdot 1 \mu \mathrm{g} / \mu \mathrm{l}$ poly (deoxyinosine-deoxycytidine) in a final volume of $40 \mu \mathrm{l}$. Protein-DNA complexes were resolved by electrophoresis through $5 \%$ native polyacrylamide gels containing $10 \%$ glycerol and $1 \times$ Tris-glycine buffer. Gels were dried under vacuum and exposed for $48-72 \mathrm{~h}$ to Amersham Hyperfilms (Amersham Pharmacia Biotech) at $80{ }^{\circ} \mathrm{C}$ with intensifying screens. Specificity of binding was ascertained by competition with a 25 -fold molar excess of unlabeled oligonucleotides.

\section{Immunocytochemistry}

AtT20 cells $\left(5 \times 10^{3}\right.$ cells/well) were plated on two-well chamber culture slides and treated with DHEA $(100 \mu \mathrm{M})$ for $24 \mathrm{~h}$. The cells were then fixed with $4 \%$ paraformaldehyde in phosphate-buffered saline (PBS), $\mathrm{pH} 7 \cdot 4$, for $10 \mathrm{~min}$ at room temperature, and incubated overnight at $4{ }^{\circ} \mathrm{C}$ with anti-NF-kB (p65) antibody (Santa Cruz Biotechnology Inc., Santa Cruz, CA, USA). Goat $\mathrm{F}\left(\mathrm{ab}^{\prime}\right) 2$ anti-mouse IgG1 fluorescein isothiocyanate (FITC) conjugate was used at a dilution of 1:200. For all fluorescent immunostaining, cell nuclei were stained with 4,6-diamidino-2-phenylindole (DAPI; 1:10 000 dilution) in $1 \times$ PBS. The coverslips mounted with DAKO fluorescent mounting medium (DAKO Corp., Carpinteria, CA, USA) were then examined with a fluorescent microscope (Olympus, Tokyo, Japan).

\section{Flow cytometry}

Flow cytometry was performed as described in the MEBCYTO apoptosis kit (Medical and Biological Laboratories Co. Ltd, Nagoya, Japan). The $\mathrm{Ca}^{2+}{ }_{-}$ dependent phospholipid-binding protein annexin $\mathrm{V}$ was used as a probe for identifying cells early in apoptosis. Unfixed AtT20 cells $\left(2 \times 10^{5}\right.$ cells $)$ which had been treated with DHEA $(100 \mu \mathrm{M})$ and $\mathrm{E}_{2}(1 \mu \mathrm{M})$ were washed twice with PBS and resuspended in a binding buffer containing $10 \mathrm{mM}$ HEPES-NaOH (pH 7.5), $140 \mathrm{mM}$ $\mathrm{NaCl}$, and $2.5 \mathrm{mM} \mathrm{CaCl}_{2}$. Cells were then incubated for 15 min with annexin V-FITC (PharMingen, San Diego, CA, USA) and propidium iodide (PI; $100 \mu \mathrm{g} / \mathrm{ml}$ ), and were subsequently analyzed by flow cytometry with a fluorescence-activated cell sorter (FACStar; Becton Dickinson, San Jose, CA, USA).

\section{3-[4,5-dimethylthiazol-2-yl]-2,5-diphenyltetrazolium bromide (MTT) assay}

MTT assay was performed using an MTT assay kit (Sigma) according to the manufacturer's instructions. Briefly, $15 \mathrm{mg}$ MTT were reconstituted in $3 \mathrm{ml}$ Hank's balanced solution (Invitrogen). After AtT20 cells were treated with DHEA $(100 \mu \mathrm{M})$ and $\mathrm{E}_{2}(1 \mu \mathrm{M})$ for $24 \mathrm{~h}$, the medium was removed, and $20 \mu \mathrm{l}$ solubilized MTT was added to each well. The plates were then incubated for $3 \mathrm{~h}$ at $37^{\circ} \mathrm{C}$ to obtain blue formazan crystals, at which time the crystals were treated with $180 \mu \mathrm{l}$ MTT solubilization solution. Plates were read immediately on a microplate reader.

\section{Xenograft experiments}

All animal studies were carried out in accordance with the Guide for the Care and Use of Laboratory Animals as adopted and promulgated by Kochi Medical School. 

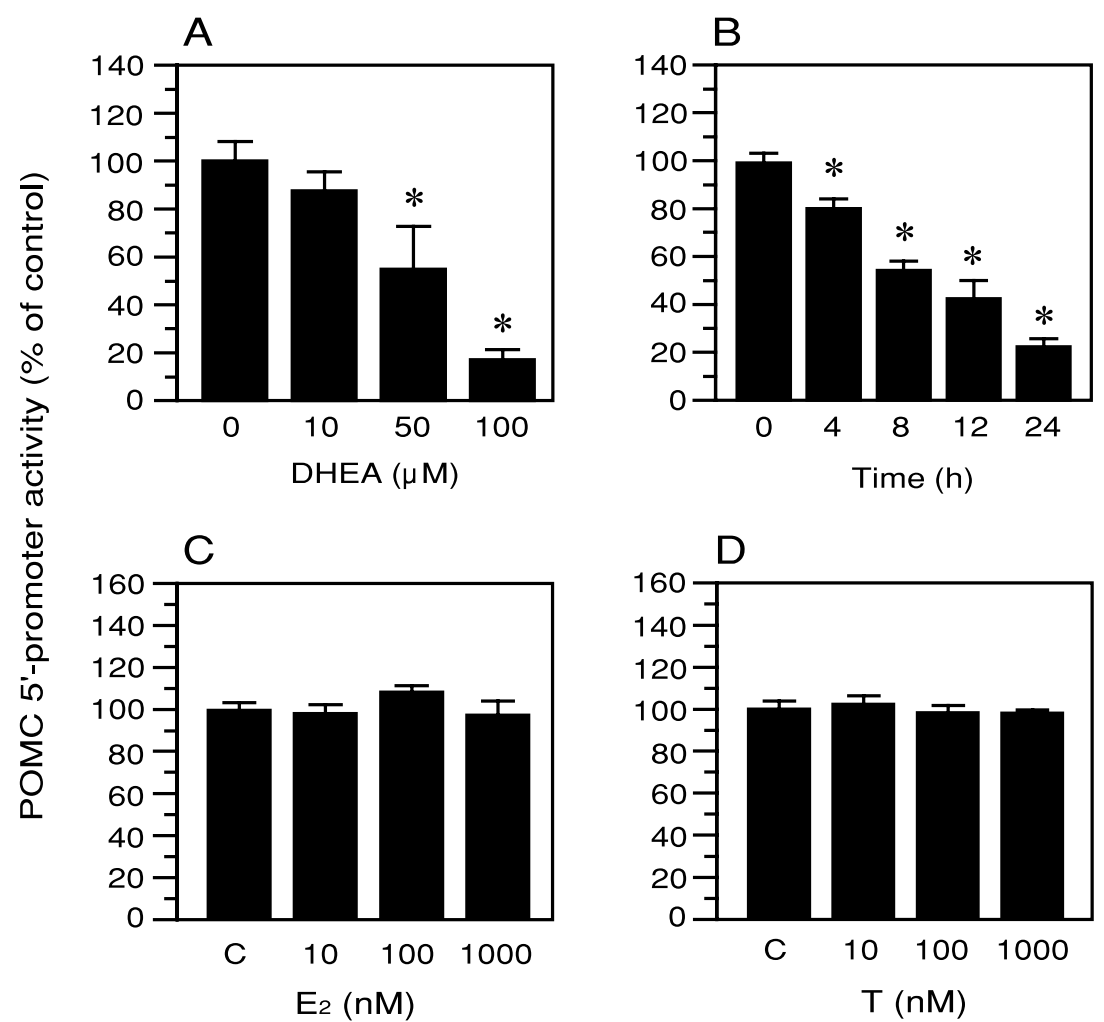

Figure 1 Effects of DHEA, $E_{2}$ and testosterone $(T)$ on POMC gene 5 '-promoter activity in AtT20PL cells. (A and B) Cells were treated with various concentration of DHEA $(10-100 \mu \mathrm{M}$ for $24 \mathrm{~h})$, or with DHEA $(100 \mu \mathrm{M})$ for defined time-intervals $(4-24 \mathrm{~h})$, and transcription activity of the POMC gene was determined by luciferase assay. ${ }^{\star} P<0 \cdot 05$ vs control $[C]$. (C and D) Similar experiments were performed with the two major metabolites of DHEA, (C) $\mathrm{E}_{2}$ (10-1000 nM for $24 \mathrm{~h}$ ) or (D) testosterone (10-1000 nM for $24 \mathrm{~h}$ ).

Sixteen male BALB/C nu/nu mice at 8 weeks of age (approximate 22-24 g) were purchased from Japan SLC Inc. (Shizuoka, Japan) and maintained in pathogen-free conditions with irradiated chow.

Mice were subcutaneously injected with AtT20 cells $\left(5 \times 10^{6} /\right.$ mouse $)$ in matrigel $(200 \mu \mathrm{l})$ and divided randomly into four groups (four mice each): control (vehicle only) group, DHEA group, PRT group, and DHEA+PRT group. DHEA (8 $\mathrm{mg} /$ mouse per day) and/or PRT ( $200 \mu \mathrm{g} /$ mouse per day) dissolved in vehicle (1 vol. 95\% ethanol mixed with 8 vol. mineral oil) (Aragno et al. 2002) were administered subcutaneously for 21 days from 1 week after AtT20 cell injection. At the end of the experiment, mice were killed, and tumor weights were measured after their careful resection and the tumors and livers were used for quantitative RT-PCR assay. Trunk blood was also collected for the corticosterone assay at the same time of day in all experiments to avoid diurnal variation. The plasma corticosterone levels were measured using commercially available RIA kits (ICN Biomedicals Inc., Costa Mesa, CA, USA).

\section{Data analysis}

All data are expressed as the means \pm S.E.M. When the statistical analyses were performed, data were compared by one-way ANOVA with Fisher's protected least squares difference test, and $P<0.05$ was considered significant.

\section{Results}

DHEA, but not $E_{2}$ or testosterone, inhibits POMC gene transcription in AtT20 cells

DHEA inhibited the $5^{\prime}$-promoter activity of the POMC gene in dose- and time-dependent manners. Significant inhibition was observed at $50 \mu \mathrm{M}$ or above, with the maximal suppressive effects at $24 \mathrm{~h}$ (Fig. $1 \mathrm{~A}$ and $\mathrm{B}$ ). This effect appeared not to be mediated by its metabolites $\mathrm{E}_{2}$ or testosterone, because effective concentration of both hormones $(10 \mathrm{nM}-1 \mu \mathrm{M})$ did not show similar effects (Fig. 1C and D). These data suggest that a pharmacological concentration of DHEA inhibits corticotroph cell function in vitro. 
A

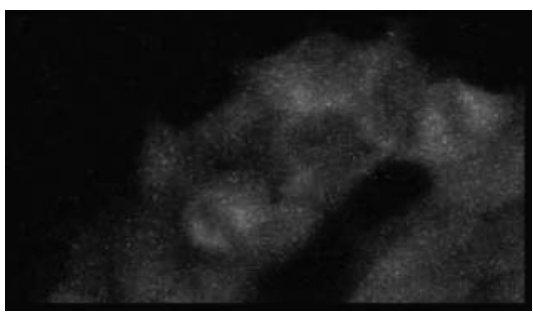

C

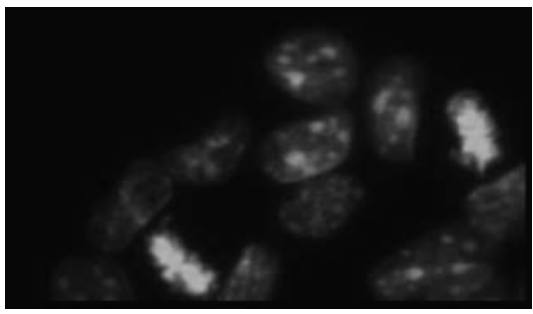

E

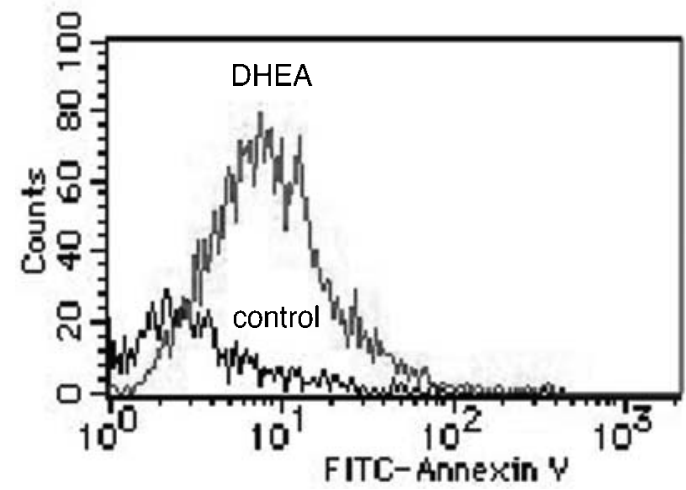

B

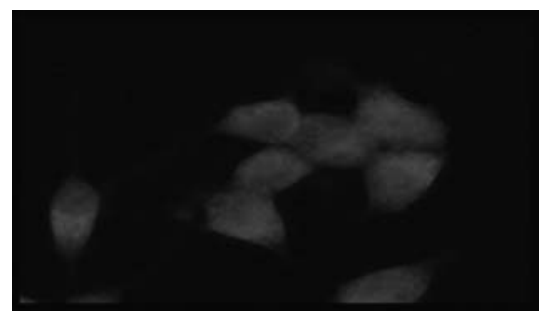

D

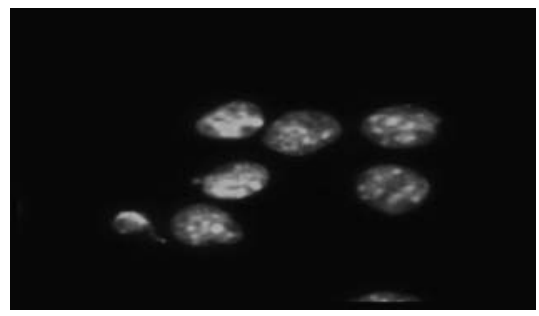

$\mathrm{F}$

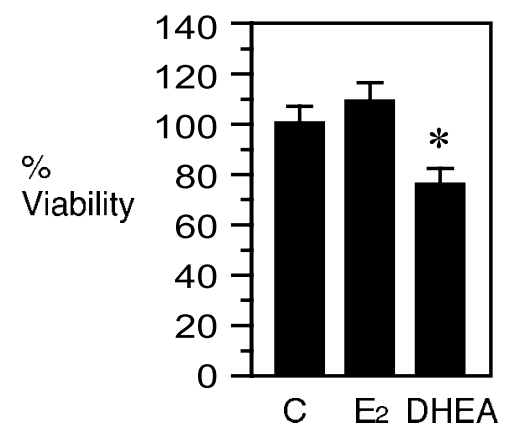

Figure 2 ( $\mathrm{A}$ and $\mathrm{B}$ ) Effects of DHEA on AtT2OPL cells using immunocytochemical staining of NF-KB. AtT20PL cells were treated with $(\mathrm{A})$ vehicle or $(\mathrm{B})$ DHEA $(100 \mu \mathrm{M})$ for $24 \mathrm{~h}$, then stained using an antibody against NF- $\kappa B$ p65 subunit, and analyzed by fluorescent microscopy $(\times 20)$. (C and D) Effect of DHEA on nuclear structure. AtT20PL cells were treated with (C) vehicle or (D) DHEA $(100 \mu \mathrm{M})$, and stained with DAPI as described in the Materials and Methods. (E and F) Cellular apoptotic change following DHEA treatment. (E) AtT20 cells were incubated with medium (control) or DHEA (100 $\mu \mathrm{M}$ for $24 \mathrm{~h}$ ), and then the expression pattern of annexin $\mathrm{V}$ was analyzed by a flow cytometric assay. (F) Alternatively, changes in cell viability were also examined using an MTT assay. $E_{2}$ was used as the active control. * $P<0.05$ vs control (C).

\section{DHEA induces apoptosis in AtT20 cells}

To clarify the mechanism responsible for the suppressive effect of DHEA on corticotroph tumor cell function, we then examined the morphological effect of DHEA on AtT20 cells by the immunofluorescence technique using NF- $\kappa B-s p e c i f i c$ antibody. In control cells, NF- $\kappa B$ p 65 protein was distributed in both cytoplasm and nuclei (Fig. 2A). When cells were treated with DHEA $(100 \mu \mathrm{M}$ for $24 \mathrm{~h}$ ), the staining pattern was not changed, but most of the cells shrank in size (Fig. 2B). Furthermore, nucleusspecific staining by immunofluorescent cytochemistry revealed marked condensation of the nuclear structure, suggesting the occurrence of apoptosis in DHEA-treated cells (Fig. 2C and D). To confirm the induction of apoptosis, we examined the effect of DHEA on AtT20 cells using a flow cytometric assay. We found that annexin V-positive and PI-negative cells, suggestive of apoptotic changes, were increased by DHEA compared with control (Fig. 2E), whereas $\mathrm{E}_{2}$ had no effect (data not shown). 
A

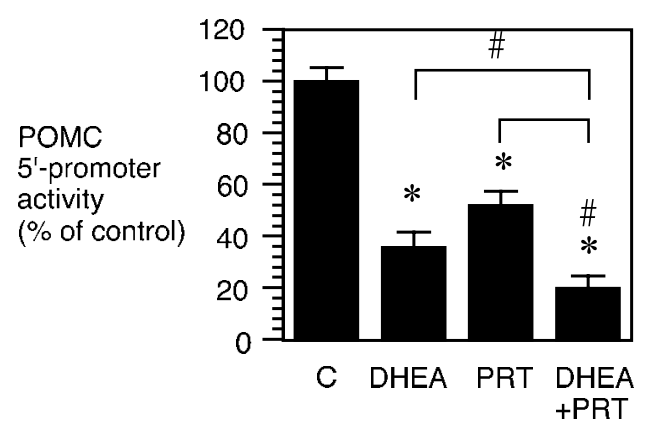

B

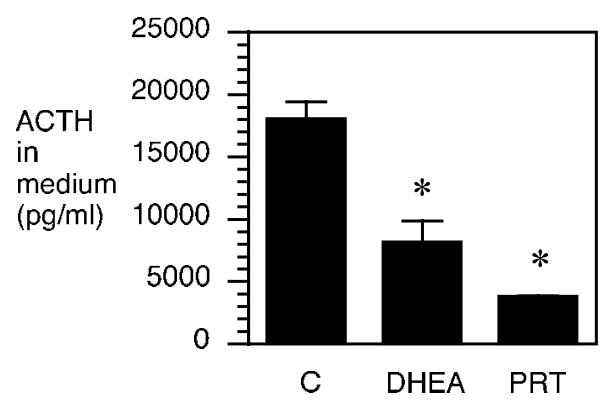

D

C

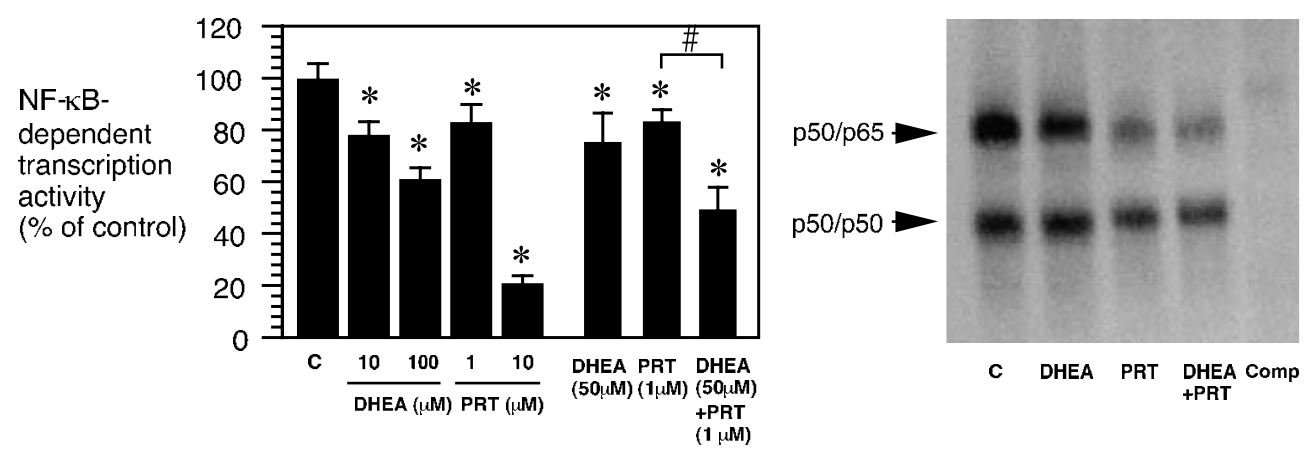

Figure 3 Effects of DHEA and PRT on corticotroph cell function. (A) AtT20PL cells were treated with DHEA $(100 \mu \mathrm{M})$ and/or PRT $(7 \mu \mathrm{M})$, and transcription activity of the POMC gene was determined by luciferase assay. ${ }^{*} P<0.05$ vs control $[C],{ }^{\#} P<0.05$ vs DHEA+PRT. (B) Cells were treated as above, and ACTH secreted into culture medium during the incubation $(24 \mathrm{~h})$ was estimated by immunoradiometric assay. ${ }^{*} P<0 \cdot 05 \mathrm{vs}$

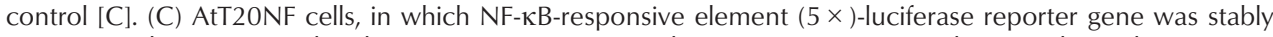

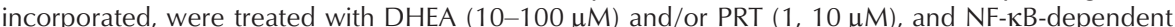
transcription activity was determined by luciferase assay. ${ }^{*} P<0.05$ vs control $[C],{ }^{\#} P<0.05$ vs PRT alone. (D) Effects of DHEA and PRT on the DNA binding of NF-KB. AtT20PL cells were treated with DHEA (100 $\mu \mathrm{M})$ and/or PRT $(10 \mu \mathrm{M})$ for $4 \mathrm{~h}$. Nuclear protein was extracted, and then applied to EMSA analysis using NF-kB-specific DNA probe. Comp, competition.

Significant reduction of cell viability by DHEA but not by $\mathrm{E}_{2}$ was also shown by MTT assay (Fig. 2F). Thus, the above results strongly suggest that DHEA suppresses corticotroph tumor cell function by inducing apoptosis.

\section{DHEA inhibits NF- $\kappa B$-mediated transcription}

Recent studies suggest that the transcription factor NF- $\mathrm{KB}$ is activated in a variety of tumor cells and exerts an anti-apoptotic effect (Pikarsky et al. 2004). Since DHEA is shown to have inhibitory effects on NF-KB-dependent transcription in other types of cell lines (Iwasaki et al. 2004), we speculated that DHEA induces apoptosis in AtT20 cells by inhibiting NF- $\kappa B$. To confirm this hypothesis, we examined the NF- $\mathrm{BB}$ inhibitor PRT on POMC expression, with the result that PRT as well as DHEA significantly inhibited both POMC gene transcription and ACTH secretion (Fig. 3A and B). Furthermore, the combination of DHEA and PRT showed an additive, more suppressive effect on POMC gene expression. A similar effect was observed on NF- $\mathrm{KB}$-mediated gene transcription (Fig. 3C). The inhibitory effects of these compounds were confirmed by EMSA analysis, although the effect of DHEA alone was less marked than that of PRT (Fig. 3D). Altogether, these results suggest that the inhibitory effect of DHEA on corticotroph cell function is, at least in part, mediated by suppression of NF- $\mathrm{\kappa B}$-mediated gene expression, with resultant induction of cellular apoptosis, although the additive effect with PRT suggests an NF-кB-independent mechanism as well.

DHEA inhibits the expression of survivin, a representative inhibitor of apoptosis protein

Recent studies suggest a pivotal role of the IAPs in maintaining the immortality of tumor cells (Yang et al. 
A
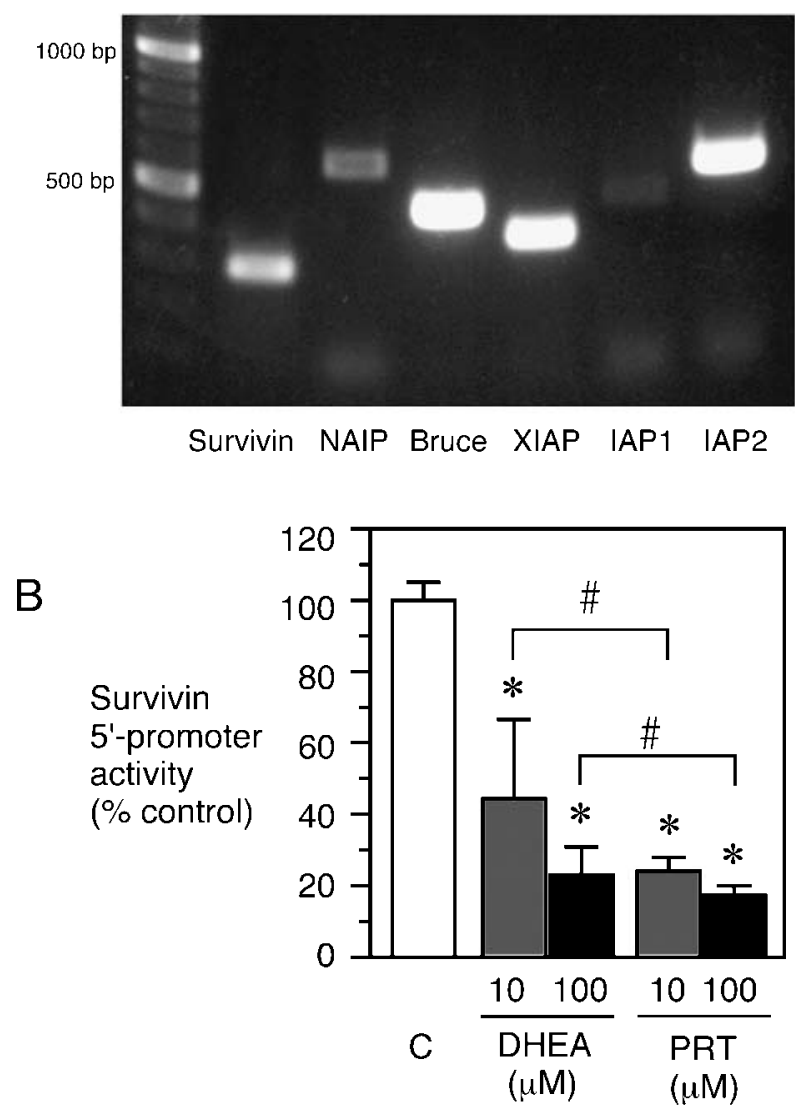

Figure 4 (A) Expression of IAPs mRNA in AtT20 cells. Total RNA was extracted from the cells, and the expression of IAPs (survivin, mNAIP, Bruce, XIAP, IAP1, IAP2) was analyzed by RT-PCR using primer sets specific to the mRNA sequence of each gene. (B) Effects of DHEA and PRT on the 5'-promoter activity of survivin gene in AtT20 cells. Cells were transfected transiently with survivin 5 '-promoter-luciferase reporter plasmid, and treated with DHEA $(10,100 \mu \mathrm{M})$ or PRT $(10,100 \mu \mathrm{M})$ for $24 \mathrm{~h}$. Then the transcription activity of survivin gene was determined by luciferase assay. ${ }^{*} P<0 \cdot 05$ vs control $[C] .{ }^{\#} P<0 \cdot 05$ vs values with $10 \mu \mathrm{M}$ test substance.

2003). Since the expressions of many of these IAP genes are known to be stimulated by an NF- $\mathrm{kB}$-dependent mechanism, we examined the expression of IAPs in AtT20 cells by RT-PCR. The results showed that a variety of IAPs such as survivin, mNAIP, Bruce, XIAP, IAP1, and IAP2 were expressed in AtT20 cells (Fig. 4A). We then focused on the expression of survivin, a representative IAP expressed in the AtT20 cell line. When cells were treated with DHEA or PRT, the transcription activity of survivin was significantly attenuated in a dose-dependent manner (Fig. 4B). Since the promoter activity of survivin has been shown to be regulated by
NF-KB (Kawakami et al. 2005), our results raise the possibility that DHEA and PRT inhibit the expression of IAPs like survivin and induce apoptosis through inhibition on the NF-KB pathway.

DHEA/PRT inhibits tumor growth and decreases plasma corticosterone in vivo in nude mice with AtT20 cell xenografts We then examined the effects of DHEA and PRT on corticotroph tumor growth and function in vivo using xenografts of AtT20 cells in nude mice, an animal model of ACTH-dependent Cushing's disease used in previous studies (Heaney et al. 2002). In control (vehicle) mice transplanted with AtT20 cells, significant tumor growth with body weight loss was observed during the time of the examination (21 days) (Figs 5 and 6A and B). The decrease in body weight was significantly attenuated by the administration of DHEA but not by PRT (Fig. 6A), and neither treatment inhibited the tumor growth (Fig. 6B). Interestingly, however, the combined administration of both DHEA and PRT significantly suppressed both body weight loss and tumor growth (Fig. 6A and B). Indeed, mice receiving the combined treatment had a markedly smaller tumor size and looked much less cachexic, compared with control mice treated with vehicle alone (Fig. 5).

To examine the possible deleterious effects of the combined administration of DHEA and PRT on nontumor cells, we examined the expression level of survivin mRNA in xenografts and in liver cells as a control, by quantitative RT-PCR. We found that survivin mRNA was detected in normal hepatocytes as well as AtT20 xenograft cells by conventional RT-PCR (Fig. 6D). When the expression level of survivin using quantitative RT-PCR was examined, we found that the combined treatment of the mice with DHEA and PRT significantly decreased the expression level of survivin mRNA in xenograft cells in vivo (Fig. 6C), whereas the same treatment did not influence survivin expression in normal hepatocytes (Fig. 6D).

Finally, we examined the plasma corticosterone levels in the nude mice xenograft model. We found that the plasma corticosterone level was significantly lower in the mice treated with DHEA alone or both DHEA and PRT, and that there was no statistically significant difference between the two groups.

\section{Discussion}

Although the first choice in the treatment of ACTHdependent Cushing's disease, either of pituitary origin or ectopic, is removal of the tumor by surgical procedure, medical therapy is sometimes needed for patients with unresectable tumor and/or recurrence/metastasis (Hammer et al. 2004). Recent studies suggest that retinoic acid and TZD such as rosiglitazone are the possible 
Day 1
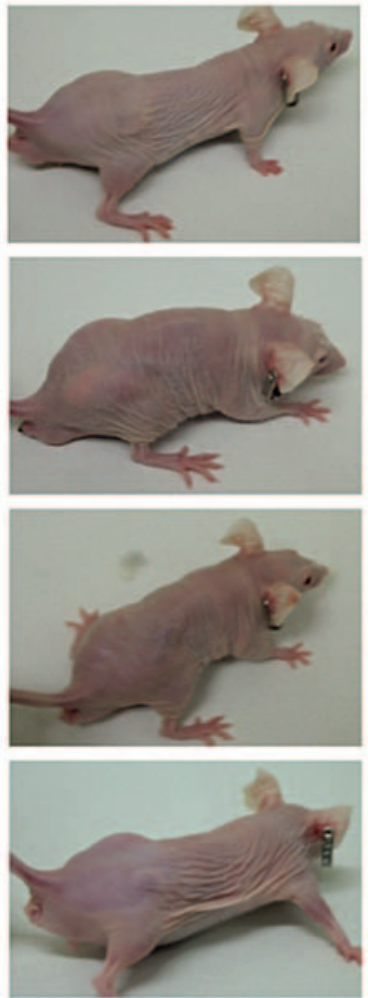

Day 7
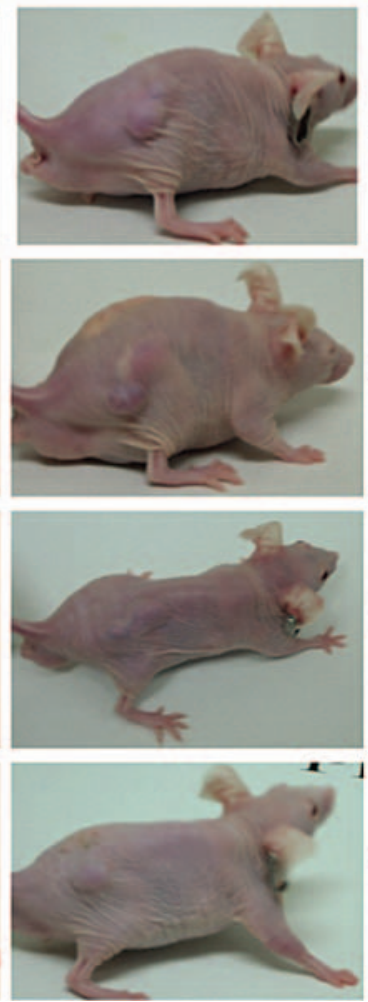

Day 14
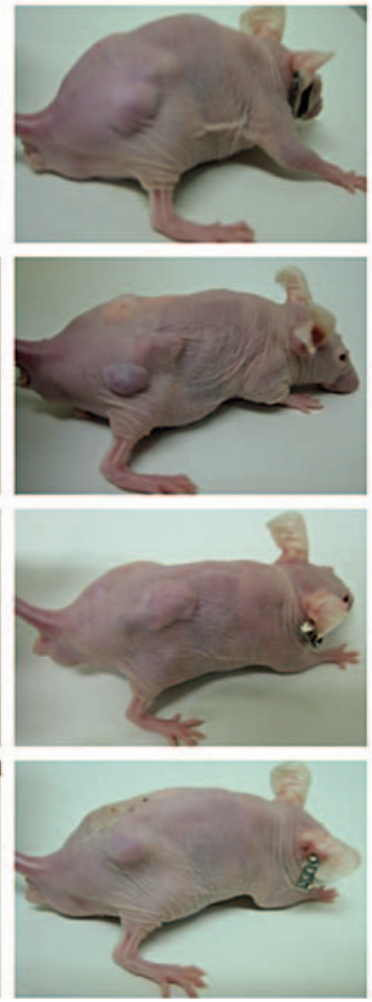

Day 21
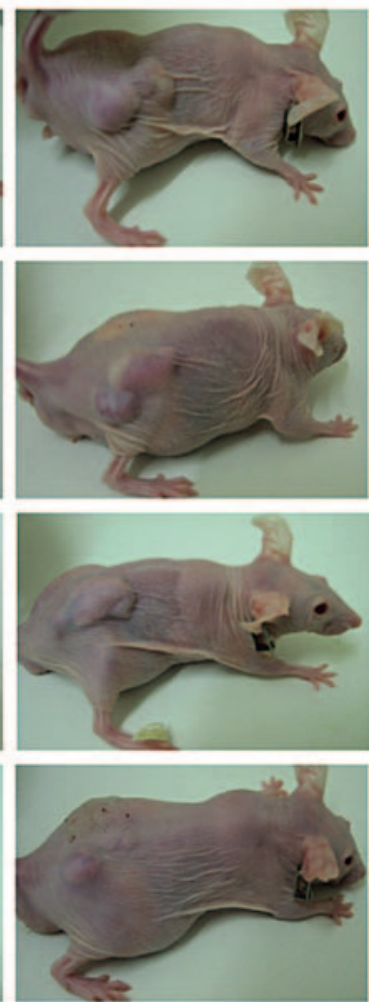

Figure 5 Effects of DHEA and/or PRT on tumor growth in the nude mouse/AtT20 xenograft model in vivo. Mice were divided into four groups (control, DHEA, PRT, and DHEA+PRT; $n=4$ in each group). All the mice received a subcutaneous xenograft of AtT20 cells $\left(5 \times 10^{6} /\right.$ mouse), and 7 days later they started to receive treatment with vehicle (control) or with DHEA ( $8 \mathrm{mg} / \mathrm{mouse}$ per day) and/or PRT $(200 \mu \mathrm{g} /$ mouse per day) for 21 days. During the experiment, the appearance of tumor mass and the nutritional condition of each mouse with xenografts were serially recorded. Representative photographs of mice in each group are shown.

candidate drugs for clinical application, and promising preliminary data are reported in the latter case (Heaney et al. 2003). In this study, we have examined the possible effects of DHEA and PRT, both of which have anti$\mathrm{NF}-\mathrm{\kappa B}$ activity with apoptosis-inducing properties on tumor cells. We found that, in vitro, both compounds decreased the activity of corticotroph tumor cells by inducing apoptosis. Furthermore, in vivo, the combination of the two drugs significantly suppressed tumor growth as well as function in mice receiving AtT20 xenografts.

DHEA is usually recognized as an adrenal sex steroid precursor, which is known to be converted to testosterone and $E_{2}$ in peripheral organs (Ebeling \& Koivisto 1994). However, DHEA may also be expected to have a variety of beneficial effects, and is sometimes used as a supplement in healthy and, especially, aged people (Baulieu 1996), although the receptor for DHEA has not been identified and the molecular mechanism remains to be clarified (Widstrom \& Dillon 2004). In the present study, we found an inhibitory effect of DHEA on POMC gene transcription in AtT20 cells in vitro. This effect seems not to be mediated by $\mathrm{E}_{2}$ or testosterone, because no direct effects of these metabolites were observed. However, the effective concentration of DHEA needed was much higher than that in the peripheral blood of healthy subjects (10-30 nM) (Iwasaki et al. 2004). This suggests that a pharmacological concentration of DHEA is needed to exert an anti-tumor effect. Recently, Iwasaki et al. (2004) reported that a high dose of DHEA and/or DHEA-sulfate exerts anti-NF- $\kappa \mathrm{B}$ effects in hepatocytes. Furthermore, a pharmacological dose of DHEA is reported to have anti-tumor effects by inducing apoptosis (Yang et al. 2000). Since NF- $\kappa B$ is an anti-apoptotic transcription factor, it is possible that DHEA exerts its anti-tumor effect by inhibiting NF- $\kappa B$ and subsequently inducing apoptosis. Indeed, in our study, we found that treatment of the cells with DHEA caused morphological changes such as nuclear condensation, which could be compatible with the occurrence of apoptosis. Furthermore, flow cytometric analysis showed the increase in annexin 
A

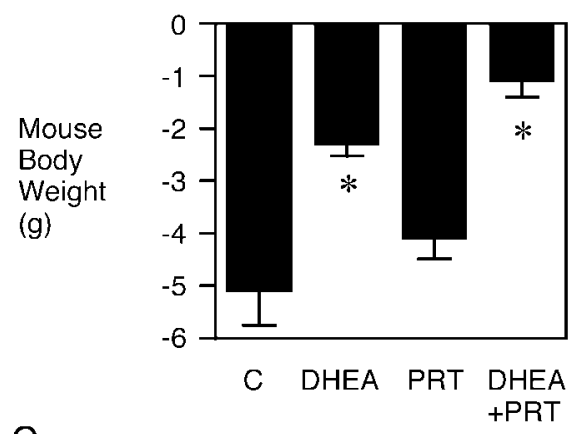

C

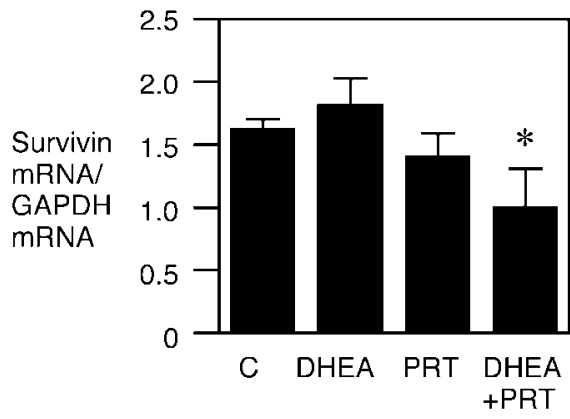

$E$

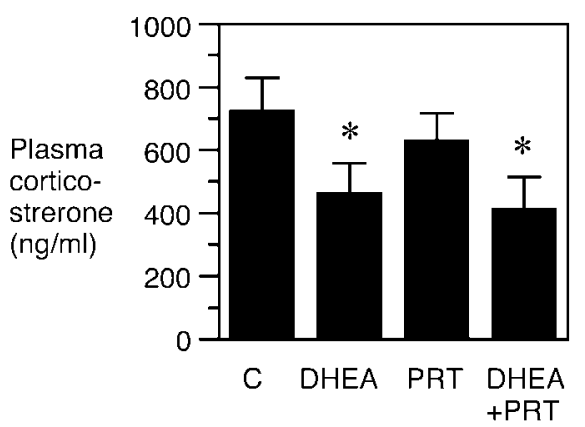

B
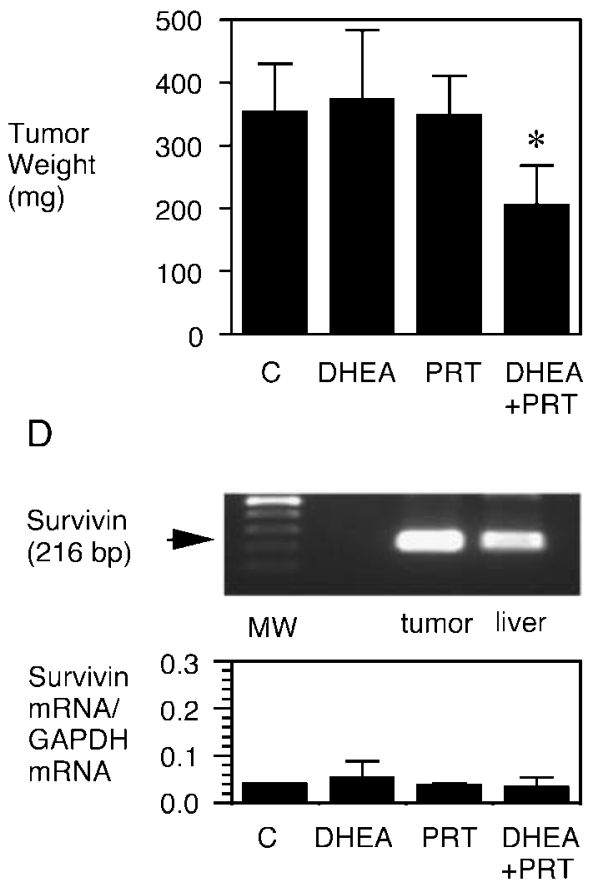

Figure 6 Effects of DHEA and/or PRT on various parameters in mouse xenograft model. (A and B) Mouse body weight and tumor weight. (A) Body weight in each mouse was determined at the end of the experiment (day 21), and compared with that at day 1. (B) At the same time, the subcutaneous tumor was resected and weighed. ${ }^{*} P<0.05$ vs control $[C]$. (C) Survivin mRNA in the xenograft. Total RNA was isolated from the grafted tumor cell at the end of experiment (day 21), and the expression level of survivin was determined by quantitative RT-PCR. GAPDH mRNA level was also estimated and used as an internal control. ${ }^{*} P<0.05$ vs control $[C]$. (D) Survivin mRNA in normal tissue (liver). Total RNA was isolated from hepatic tissues, and analyzed by conventional RT-PCR (upper panel) or by quantitative real-time RT-PCR as control. (E) Plasma corticosterone levels. Peripheral blood of each mouse was obtained at the end of experiment (day 21), and applied for the RIA of corticosterone. * $P<0 \cdot 05$ vs control [C].

V-positive and PI-negative cells following DHEA treatment, further confirming the apoptosis-inducing effect of the hormone.

$\mathrm{NF}-\mathrm{\kappa B}$ is a transcription factor which is involved in inflammation/cytokine-mediated gene transcription. However, the factor is frequently activated in tumor cells, and possibly makes the cells anti-apoptotic and immortalized. In AtT20 cells, NF-KB is suggested to be involved in
POMC gene transcription following immunological stimuli (Kovalovsky et al. 2004). Furthermore, it is well known that NF- $\kappa B$ induces a variety of IAPs such as survivin, mNAIP, Bruce, XIAP, IAP1, and IAP2, all of which we confirmed to be expressed in AtT20 cells as well. Thus, it is reasonable that inhibition of NF- $\mathrm{KB}$ causes apoptosis by decreasing survivin and other IAPs, as well as by decreasing the POMC expression. 
DHEA and PRT showed an additive effect on POMC as well as NF-KB-dependent gene transcription in vitro, suggesting that the two compounds have differing effects on NF- $\mathrm{KB}$ function. PRT is known to exert an anti$\mathrm{NF}-\kappa \mathrm{B}$ effect by inactivating inhibitory $\mathrm{kB}(\mathrm{IkB})$ kinase (Kwok et al. 2001). DHEA, in contrast, may inhibit $\mathrm{NF}-\kappa \mathrm{B}$ through its antioxidant effect by altering the intracellular redox state (Gao et al. 2005, Kabe et al. 2005), through inhibition of $\mathrm{I} \kappa \mathrm{B}$ ubiquitination is shown in diabetic rats (Aragno et al. 2002), or through activation of PPAR $\alpha$ (Kochan \& Karbowska 2004). Thus, we assume that the combined effects of the two drugs are caused, at least partly, by their inhibitory effects on NF- $\mathrm{KB}$ function, although the effects on other signaling pathway(s) are not ruled out.

The additive effects of DHEA and PRT were also observed in vivo, especially in anti-tumor growth and anti-survivin effects. In these cases, administration of DHEA or PRT alone was not effective, and this may simply be because the blood level of each drug was less than that which we tested in vitro. Interestingly, DHEA alone had a significant inhibitory effect both on plasma corticosterone levels and on the cachexic effect; this also suggests that DHEA and PRT are acting partly through different molecular mechanisms. In the former case, Chang et al. (2003) reported the direct effect of DHEA on adrenal cells to inhibit corticosterone secretion by inhibiting steroidogenic enzymes downstream from cytochrome P450 side-chain cleavage enzyme (scc) and by inhibiting steroidogenic acute regulatory protein (StAR) expression. Thus, we assume that the combined use of DHEA and PRT is more efficient for inhibiting both growth and function of corticotroph tumor cells.

Because NF- $\mathrm{KB}$ is known to play an important role in normal cell function (Barnes \& Karin 1997), inhibition of $\mathrm{NF}-\kappa \mathrm{B}$ may cause adverse effects in non-tumor cells. However, mice treated with both DHEA and PRT had much less weight loss and cachexia compared with control xenograft mice, and no tendency to immunodeficiency was observed. We also confirmed in vivo that the combined use of DHEA and PRT did not affect the expression of survivin mRNA in a normal organ like the liver. Thus, we assume that inhibition of NF- $\kappa B$ by these two drugs does not cause deleterious effect(s) on non-tumor tissues/cells, as far as we observed in our animal model.

DHEA is a endogenous hormone, has virtually no toxicity, and indeed is used frequently as a supplement in healthy people (Villareal \& Holloszy 2004). PRT is also already used for the treatment of malignant lymphoma and other tumors in clinical practice (Ross et al. 1999, Curry et al. 2004). Furthermore, each drug has properties to inhibit corticotroph cell function as well as growth, and simultaneous administration shows significant additive effects both in vitro and in vivo. Therefore, the combination of these two compounds might be suitable in functional endocrine neoplasia like corticotroph tumor although further basic studies are absolutely necessary.

\section{Acknowledgements}

The authors are indebted to Ms Reiko Matsumoto and Machiko Kambayashi for their excellent technical assistance. This work is supported in part by a Grant-in-Aid from the Japanese Ministry of Health, Labour and Welfare. The authors declare that there is no conflict of interest that would prejudice the impartiality of this scientific work.

\section{References}

Ambrosini G, Adida C \& Altieri DC 1997 A novel anti-apoptosis gene, survivin, expressed in cancer and lymphoma. Nature Medicine 3 917-921.

Aoki K, Nakajima A, Mukasa K, Osawa E, Mori Y \& Sekihara H 2003 Prevention of diabetes, hepatic injury, and colon cancer with dehydroepiandrosterone. Journal of Steroid Biochemistry and Molecular Biology 85 469-472.

Aragno M, Mastrocola R, Brignardello E, Catalano M, Robino G, Manti R, Parola M, Danni O \& Boccuzzi G 2002 Dehydroepiandrosterone modulates nuclear factor- $\kappa \mathrm{B}$ activation in hippocampus of diabetic rats. Endocrinology 143 3250-3258.

Arnaldi G, Angeli A, Atkinson AB, Bertagna X, Cavagnini F, Chrousos GP, Fava GA, Findling JW, Gaillard RC, Grossman AB et al. 2003 Diagnosis and complications of Cushing's syndrome: a consensus statement. Journal of Clinical Endocrinology and Metabolism 88 5593-5602.

Aziz MH, Ghotra AS, Shukla Y \& Ahmad N 2004 Ultraviolet-B radiation causes an upregulation of survivin in human keratinocytes and mouse skin. Photochemistry and Photobiology 80 602-608.

Barnes PJ \& Karin M 1997 Nuclear factor-КB: a pivotal transcription factor in chronic inflammatory diseases. New England Journal of Medicine 336 1066-1071.

Baulieu EE 1996 Dehydroepiandrosterone (DHEA): a fountain of youth? Journal of Clinical Endocrinology and Metabolism $\mathbf{8 1}$ 3147-3151.

Chang LL, Wun WS, Ho LL \& Wang PS 2003 Effects of dehydroepiandrosterone on corticosterone release in rat zona fasciculata-reticularis cells. Naunyn Schmiedeberg's Archive of Pharmacology 368 487-495.

Curry EA, Murry DJ, Yoder C, Fife K, Armstrong V, Nakshatri H, O'Connell M \& Sweeney CJ 2004 Phase I dose escalation trial of feverfew with standardized doses of parthenolide in patients with cancer. Investigational New Drugs 22 299-305.

Ebeling P \& Koivisto VA 1994 Physiological importance of dehydroepiandrosterone. Lancet 343 1479-1481.

Gao J, Sun HY, Zhu ZR, Ding Z \& Zhu L 2005 Antioxidant effects of dehydroepiandrosterone are related to up-regulation of thioredoxin in SH-SY5Y cells. Acta Biochimica et Biophysica Sinica 37 119-125.

Hammer GD, Tyrrell JB, Lamborn KR, Applebury CB, Hannegan ET, Bell S, Rahl R, Lu A \& Wilson CB 2004 Transsphenoidal microsurgery for Cushing's disease: initial outcome and long-term results. Journal of Clinical Endocrinology and Metabolism 89 6348-6357.

Heaney AP, Fernando M, Yong WH \& Melmed S 2002 Functional PPAR- $\gamma$ receptor is a novel therapeutic target for ACTH-secreting pituitary adenomas. Nature Medicine 8 1281-1287. 
Heaney AP, Fernando M \& Melmed S 2003 PPAR $-\gamma$ receptor ligands: novel therapy for pituitary adenomas. Journal of Clinical Investigation 111 1381-1388.

Horiguchi Y, Kuroda K, Nakashima J, Murai M \& Umezawa K 2003 Antitumor effect of a novel nuclear factor- $\mathrm{KB}$ activation inhibitor in bladder cancer cells. Expert Review of Anticancer Therapy 3 793-798.

Iwasaki Y, Asai M, Yoshida M, Nigawara T, Kambayashi M \& Nakashima N 2004 Dehydroepiandrosterone-sulfate inhibits nuclear factor- $\kappa \mathrm{B}$-dependent transcription in hepatocytes, possibly through antioxidant effect. Journal of Clinical Endocrinology and Metabolism 89 3449-3454.

Kabe Y, Ando K, Hirao S, Yoshida M \& Handa H 2005 Redox regulation of NF-KB activation: distinct redox regulation between the cytoplasm and the nucleus. Antioxidants and Redox Signaling 7 395-403.

Kawakami H, Tomita M, Matsuda T, Ohta T, Tanaka Y, Fujii M, Hatano M, Tokuhisa T \& Mori N 2005 Transcriptional activation of survivin through the NF- $\kappa \mathrm{B}$ pathway by human T-cell leukemia virus type I tax. International Journal of Cancer 115 967-974.

Kochan Z \& Karbowska J 2004 Dehydroepiandrosterone up-regulates resistin gene expression in white adipose tissue. Molecular and Cellular Endocrinology 218 57-64.

Kovalovsky D, Paez Pereda M, Labeur M, Renner U, Holsboer F, Stalla GK \& Arzt E 2004 Nur77 induction and activation are necessary for interleukin-1 stimulation of proopiomelanocortin in AtT-20 corticotrophs. FEBS Letters 563 229-233.

Kwok BH, Koh B, Ndubuisi MI, Elofsson M \& Crews CM 2001 The anti-inflammatory natural product parthenolide from the medicinal herb feverfew directly binds to and inhibits IкB kinase. Chemistry and Biology 8 759-766.

LaCasse EC, Baird S, Korneluk RG \& MacKenzie AE 1998 The inhibitors of apoptosis (IAPs) and their emerging role in cancer. Oncogene 17 3247-3259.

Liang J, Yao G, Yang L \& Hou Y 2004 Dehydroepiandrosterone induces apoptosis of thymocyte through Fas/Fas-L pathway. International Immunopharmacolog 4 1467-1475.

Lu M, Kwan T, Yu C, Chen F, Freedman B, Schafer JM, Lee EJ, Jameson JL, Jordan VC \& Cryns VL 2005 Peroxisome proliferator-activated receptor $\gamma$ agonists promote TRAIL-induced apoptosis by reducing survivin levels via cyclin D3 repression and cell cycle arrest. Journal of Biological Chemistry 280 6742-6751.

Miller WL 2002 Androgen biosynthesis from cholesterol to DHEA. Molecular and Cellular Endocrinology 198 7-14.

Nakshatri H, Rice SE \& Bhat-Nakshatri P 2004 Antitumor agent parthenolide reverses resistance of breast cancer cells to tumor necrosis factor-related apoptosis-inducing ligand through sustained activation of c-Jun N-terminal kinase. Oncogene 23 7330-7344.

Paez-Pereda M, Kovalovsky D, Hopfner U, Theodoropoulou M, Pagotto U, Uhl E, Losa M, Stalla J, Grubler Y, Missale C et al. 2001 Retinoic acid prevents experimental Cushing syndrome. Journal of Clinical Investigation 108 1123-1131.

Patel NM, Nozaki S, Shortle NH, Bhat-Nakshatri P, Newton TR, Rice S, Gelfanov V, Boswell SH, Goulet RJ Jr, Sledge GW Jr et al. 2000 Paclitaxel sensitivity of breast cancer cells with constitutively active NF- $\kappa \mathrm{B}$ is enhanced by $\mathrm{I} \kappa \mathrm{B} \alpha$ super-repressor and parthenolide. Oncogene 19 4159-4169.

Pikarsky E, Porat RM, Stein I, Abramovitch R, Amit S, Kasem S, Gutkovich-Pyest E, Urieli-Shoval S, Galun E \& Ben-Neriah Y $2004 \mathrm{NF}-\mathrm{KB}$ functions as a tumour promoter in inflammation-associated cancer. Nature 431 461-466.

Riggins RB, Zwart A, Nehra R \& Clarke R 2005 The nuclear factor $\kappa \mathrm{B}$ inhibitor parthenolide restores ICI 182,780 (Faslodex; fulvestrant)-induced apoptosis in antiestrogen-resistant breast cancer cells. Molecular Cancer Therapy 4 33-41.

Ross JJ, Arnason JT \& Birnboim HC 1999 Low concentrations of the feverfew component parthenolide inhibit in vitro growth of tumor lines in a cytostatic fashion. Planta Medica 65 126-129.

Salvesen GS \& Duckett CS 2002 IAP proteins: blocking the road to death's door. Nature Reviews in Molecular and Cellular Biology 3 401-410.

Schimmer AD 2004 Inhibitor of apoptosis proteins: translating basic knowledge into clinical practice. Cancer Research 64 7183-7190.

Shiau CW, Yang CC, Kulp SK, Chen KF, Chen CS, Huang JW \& Chen CS 2005 Thiazolidenediones mediate apoptosis in prostate cancer cells in part through inhibition of $\mathrm{Bcl}-\mathrm{xL} / \mathrm{Bcl}-2$ functions independently of PPAR $\gamma$. Cancer Research 65 1561-1569.

Swana HS, Grossman D, Anthony JN, Weiss RM \& Altieri DC 1999 Tumor content of the antiapoptosis molecule survivin and recurrence of bladder cancer. New England Journal of Medicine 341 452-453.

Umezawa K \& Chaicharoenpong C 2002 Molecular design and biological activities of NF- $\mathrm{KB}$ inhibitors. Molecules and Cells 14 163-167.

Villareal DT \& Holloszy JO 2004 Effect of DHEA on abdominal fat and insulin action in elderly women and men: a randomized controlled trial. Journal of the American Medical Association $2922243-2248$.

Widstrom RL \& Dillon JS 2004 Is there a receptor for dehydroepiandrosterone or dehydroepiandrosterone sulfate? Seminars in Reproductive Medicine 22 289-298.

Yang L, Cao Z, Yan H \& Wood WC 2003 Coexistence of high levels of apoptotic signaling and inhibitor of apoptosis proteins in human tumor cells: implication for cancer specific therapy. Cancer Research 63 6815-6824.

Yang NC, Jeng KC, Ho WM, Chou SJ \& Hu ML 2000 DHEA inhibits cell growth and induces apoptosis in BV-2 cells and the effects are inversely associated with glucose concentration in the medium. Journal of Steroid Biochemistry and Molecular Biology 75 159-166.

Received 7 July 2005

Accepted 2 November 2005

Made available online as an Accepted Preprint 18 November 2005 